\title{
Influence of visible light and room temperature on cell proliferation in preimplantation rabbit embryos*
}

\author{
A. Schumacher and B. Fischer \\ Department of Anatomy \& Reproductive Biology, Medical Faculty, RWTH Aachen, \\ D-5100 Aachen, Federal Republic of Germany
}

\begin{abstract}
Summary. During in-vitro culture rabbit early cleavage stages (Day 1 p.c.) and compacted morulae (Day 3 p.c.) were exposed to visible light or to room temperature $\left(23^{\circ} \mathrm{C}\right)$ for various lengths of time $(0 \cdot 5-24 \mathrm{~h})$. The light source used resembled closely routine laboratory lighting. Controls were cultured simultaneously for $24 \mathrm{~h}$ under standard conditions $\left(37^{\circ} \mathrm{C}\right.$, darkness). Development was assessed by incorporation of tritiated thymidine as an indicator of cell proliferation.

In comparison to non-exposed controls cell proliferation of Day-1 embryos was more impaired by light than by room temperature whereas in Day-3 embryos thymidine incorporation was more reduced following exposure to room temperature than to light. No statistically significant decrease in thymidine incorporation was detectable up to $1 \mathrm{~h}$ (light) and $8 \mathrm{~h}$ (room temperature) in Day-1 embryos. Morulae tolerated room temperature and visible light for up to $3 \mathrm{~h}$ and $8 \mathrm{~h}$, respectively. Splitdose exposure (e.g. $4 \times 1 \mathrm{~h}$ ) to visible light or room temperature revealed no statistically significant differences compared with one long en-bloc exposure (e.g. $1 \times 4 \mathrm{~h}$ ). These results demonstrate a stage-dependent susceptibility of preimplantation embryos to physical environmental factors. The major risk, indicated by the shortest tolerance times, was provoked by visible light to early cleavage stages.
\end{abstract}

Keywords: light; room temperature; preimplantation embryos; cell proliferation; rabbit

\section{Introduction}

Although in-vitro culture of preimplantation embryos is a well established technique, surprisingly little information is available concerning the influence of physical factors on embryos. During recovery and handling oocytes and embryos are almost inevitably exposed to visible light and reduced temperatures compared to physiological conditions in vivo.

Visible light is reported to provoke a delay in cleavage of rabbit embryos (Daniel, 1964) and to disturb the completion of meiosis in fertilized hamster oocytes (Hirao \& Yanagimachi, 1978a). In contrast to these scanty data concerning light exposure, there has been more investigation of the viability of oocytes and embryos stored below $37^{\circ} \mathrm{C}$. Several events in early development have been shown to be temperature dependent, e.g. oocyte maturation and viability (Lenz et al., 1983; Katska \& Smorag, 1985; Moor \& Crosby, 1985; Syms et al., 1985; Barros et al., 1986; Morstin \& Katska, 1986), post-fusion events (Hirao \& Yanagimachi, 1978b) and cell proliferation and viability of cleavage stages (Chang, 1947, 1948a, b, c; Hafez, 1963, 1969; Whittingham \& Wales, 1969) and blastocysts (Chang, 1950). Most of these investigations, however, focussed on storage and cryopreservation of oocytes and embryos (for review see Wilmut, 1986). Routine working conditions in

*Reprint requests to B. Fischer. 
basic research as well as in human in-vitro fertilization/embryo transfer programmes involve temperatures which are far from those used for long-time preservation.

The purpose of the present study was to assess systematically the potential risk of short-term exposures to room temperature or to visible light for preimplantation embryos. Rabbit embryos of different developmental stages were chosen to disclose possible stage-specific reactions towards these physical factors.

\section{Materials and Methods}

Embryos and in-vitro culture. The superovulation procedure, embryo recovery and in-vitro culture were performed as previously described by Fischer (1987) and Fischer \& Meuser-Odenkirchen (1988). Briefly, preimplantation embryos were collected from FSH-primed rabbits of mixed breed 26 or $72 \mathrm{~h}$ after mating (p.c.) and injection of hCG. Two-cell embryos and compacted morulae were recovered by flushing the oviducts with BSM II (Maurer, 1978) containing 0.1\% bovine serum albumin (BSA). After washing 5 times, embryos from all donors were pooled and allocated randomly to the various experimental groups. Embryos were cultured in BSM II containing $1.5 \%$ BSA in a humidified atmosphere of $5 \%$ $\mathrm{CO}_{2}$ in air in water-jacketed incubators at $37^{\circ} \mathrm{C}$. Experiments with early cleavage stages and morulae were run separately.

Exposure. In total, experimental procedures and in-vitro culture lasted for $24 \mathrm{~h}$. Embryos were exposed to routine laboratory light or to room temperature. The light source used was a neon tube (Philips, TL 8W/33), kept inside the incubator, with emission in the $320-740 \mathrm{~nm}$ range (see Fig. I). The neon tube was installed $12 \mathrm{~cm}$ above the culture dish lid. Light intensity at that distance was $1600 \mathrm{~lx}$. The purpose of this arrangement was to imitate strictly the routine working conditions in our sterile laminar flow hood. Temperature was controlled and a heating effect due to the neon tube was excluded. Unexposed controls were cultured simultaneously in a second incubator for $24 \mathrm{~h}$ in darkness under standardized conditions as described above. To investigate the influence of room temperature, heating of the incubator was switched off several days before the start of experiments, and the temperature within the incubator decreased to the environmental level $\left(23^{\circ} \mathrm{C}\right)$. During experiments the temperature changed $\pm 1^{\circ} \mathrm{C}$.

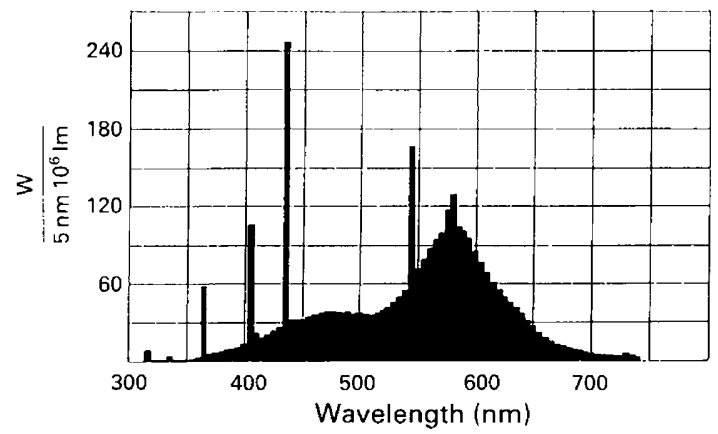

Fig. 1. Spectrum of the neon tube showing emission in the $320-740 \mathrm{~nm}$ range.

Embryos were subjected to both physical factors for various lengths of time (see Table 1). After exposure, culture dishes were removed from the first into the second incubator where they were cultured for the remaining time in the same way as controls, for example for $20 \mathrm{~h}$ after $4 \mathrm{~h}$ exposure. In split-dose experiments exposure times were distributed homogeneously over the 24-h experimental period, e.g. $4 \times 1 \mathrm{~h}$ exposure $=1 \mathrm{~h}$ exposure and $5 \mathrm{~h}$ standard culture conditions alternating. After the $24 \mathrm{~h}$ experimental period embryos were classified morphologically and labelled with $\left[{ }^{3} \mathrm{H}\right]$ thymidine.

Thymidine incorporation. Cell proliferation of embryos was evaluated by incorporation of tritiated thymidine as described in detail by Fischer (1987). Day-1 embryos were incubated in $25 \mu \mathrm{Ci}$ methyl- $\left[{ }^{3} \mathrm{H}\right]$ thymidine/ml (sp. act. $25 \mathrm{Ci} / \mathrm{mmol}$ or $925 \mathrm{GBq} / \mathrm{mmol}$; Amersham Buchler, Braunschweig, F.R.G.) for $6 \mathrm{~h}$. Day-3 embryos were labelled with $5 \mu \mathrm{Ci}$ methyl- $\left[{ }^{3} \mathrm{H}\right]$ thymidine $/ \mathrm{ml}$ (sp. act. $5 \mathrm{Ci} / \mathrm{mmol}$ or $185 \mathrm{GBq} / \mathrm{mmol}$; Amersham Buchler) for $4 \mathrm{~h}$. Incubation periods and specific activities were chosen to obtain valid incorporation data on the one hand and to avoid radiotoxic effects due to prolonged exposure to isotopes on the other (for further details see Fischer, 1987).

Preparation of embryos for liquid scintillation counting involved washing for 5 times in cold phosphate-buffered saline (PBS; Dulbecco \& Vogt, 1954), followed by precipitation with trichloroacetic acid and addition of a tissue homogenizer (Lumasolve: Lumac, Schaesberg, The Netherlands) as well as neutralization with glacial acetic acid. Liquid scintillation counting was carried out in an LKB RackBeta 1219 (tritium efficiency of 58\%; scintillation fluid: 
Table 1. Experimental protocols

\begin{tabular}{llc}
\hline $\begin{array}{l}\text { Physical } \\
\text { factor }\end{array}$ & \multicolumn{1}{c}{$\begin{array}{c}\text { Exposure time } \\
\text { (h) }\end{array}$} & $\begin{array}{c}\text { Embryo stage } \\
\text { (days post coitum) }\end{array}$ \\
\hline Visible light & $0.5,1,2,3$, & 1 \\
& $4,8,12,24$ & 3 \\
& $2,4,8,12,24$ & 1 \\
& $4 \times 0.5$ & \\
$4 \times 1$ & 1 \\
\hline Room temperature & $2,4,5,6$, \\
& $7,8,12,24$ & \\
& $2,3,4$, & 3 \\
& $8,12,24$ & 3 \\
& $3 \times 2$ & 3 \\
\hline
\end{tabular}

Lipoluma, Lumac). Most embryos were processed individually. Results are expressed as mean percentages \pm s.e.m. of control incorporation values.

Data were derived from at least 3 replicates. Split-dose treatments were performed in two series of experiments.

Statistical analyses. Reduction in cell proliferation was analysed by a pair-wise comparison of thymidine incorporation in exposed and control embryos using the non-parametric Mann-Whitney test. Due to variations in incorporation data between individual experiments, each replicate was analysed independently. The threshold value was defined by first evidence of damage, i.e. by statistically significant decreased thymidine incorporation.

\section{Results}

\section{Exposure to visible light}

The first statistically significant impairment of thymidine incorporation was found in Day-1 embryos (Fig. 2a) at $1 \mathrm{~h}$ exposure $(P<0.05)$ and in morulae (Fig. $2 \mathrm{~b})$ at $8 \mathrm{~h}(P<0.05)$. At the longest exposure time investigated $(24 \mathrm{~h}) 2$-cell stages incorporated $<20 \%$ that for unexposed controls, whereas in compacted morulae incorporation levels still amounted to $\sim 60 \%$ at that time. In Day-1 embryos exposure to visible light as split-dose treatment or as one long en-bloc exposure (Fig. 3a) did not lead to a different response $(P>0.05)$.

\section{Exposure to room temperature}

Room temperature displayed a less harmful effect on Day-1 cleavage stages than did lighting. Thymidine incorporation was significantly decreased at $8 \mathrm{~h}$ exposure (Fig. $4 \mathrm{a} ; P<0.05$ ). Compared with light exposure, variation in incorporation data was notably increased (Figs 2a, 4a). In Day-3 morulae impairment of thymidine incorporation was first detectable at $3 \mathrm{~h}$ exposure (Fig. $4 \mathrm{~b} ; P<0.05$ ). Symptomatic for the differences in susceptibility to room temperature exposure were the incorporation levels persisting after $24 \mathrm{~h}$ exposure: values ranged from $65 \%$ of controls for $2-$ cell embryos to $24 \%$ of controls for compacted morulae. Split-dose exposures of Day-3 embryos to room temperature did not result in different incorporation data compared with single dose exposures (Fig. 3b; $P>0.05$ ).

\section{Discussion}

A stage-dependent susceptibility to visible light and room temperature is demonstrable by impairment of cell proliferation in preimplantation rabbit embryos. With cleavage progressing from the 


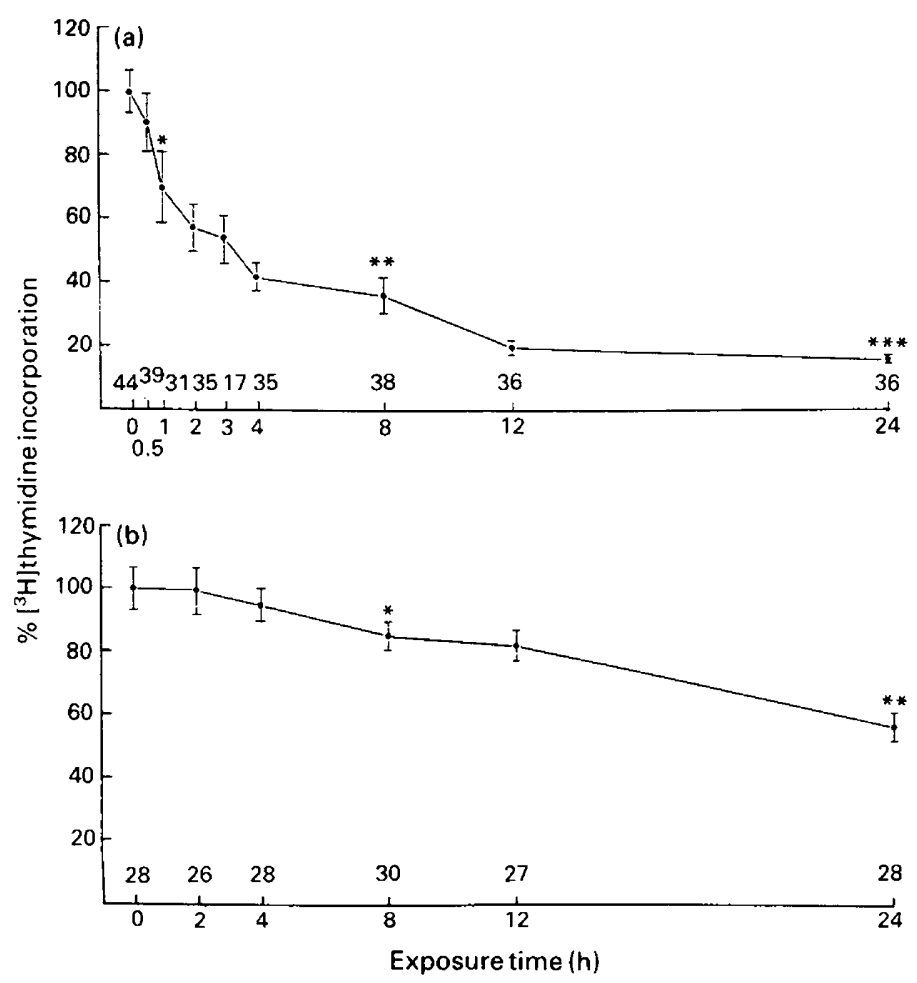

Fig. 2. $\left[{ }^{3} \mathrm{H}\right]$ Thymidine incorporation (as \% of non-exposed controls) in (a) Day-1 and (b) Day-3 rabbit embryos exposed to visible light. Values are mean \pm s.e.m. for the no. of embryos indicated. For (a), controls $(0 \mathrm{~h})=314 \pm 27 \mathrm{~d} . \mathrm{p} . \mathrm{m}$./embryo; for $(\mathrm{b})$, controls $(0 \mathrm{~h})=$ $2157 \pm 200$ d.p.m./embryo. ${ }^{*} P<0.05 ;{ }^{* *} P<0.01 ;{ }^{* * *} P<0.001$ compared with controls $(0 \mathrm{~h})$.
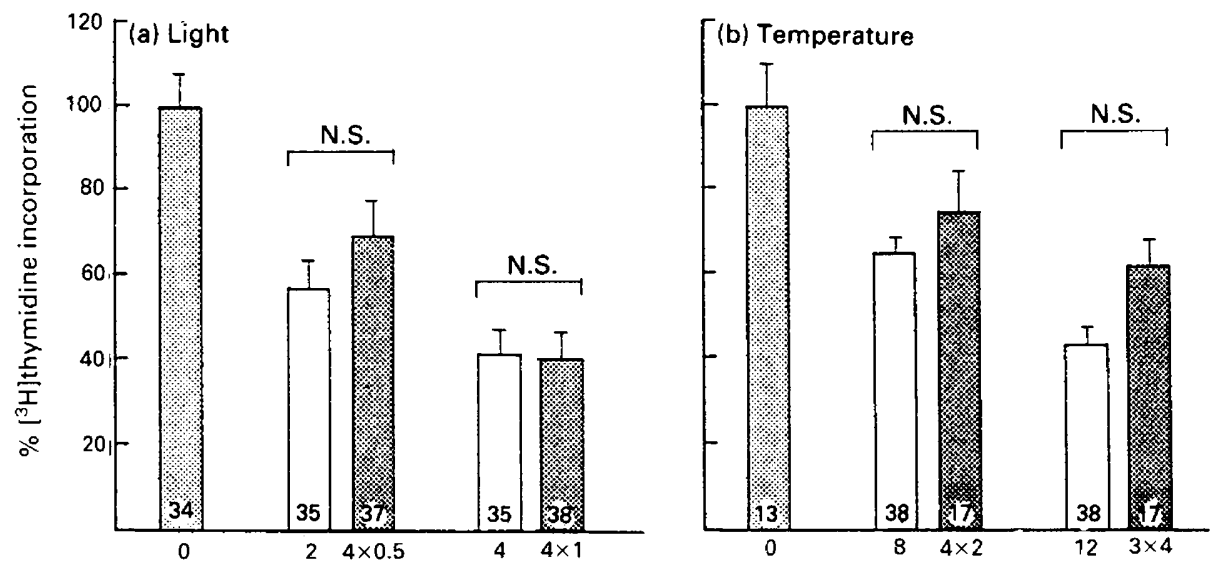

Exposure time (h)

Fig. 3. $\left[{ }^{3} \mathrm{H}\right]$ Thymidine incorporation (as \% of non-exposed controls) in (a) Day-1 rabbit embryos exposed to split doses of visible light (stippled columns) and (b) Day-3 rabbit embryos exposed to split doses of room temperature (stippled columns). Open columns are exposures in single blocks. Values are mean \pm s.e.m. for the no. of embryos indicated. For (a), controls $(0 \mathrm{~h})=511 \pm 45$ d.p.m./embryo; for $(\mathrm{b})$, controls $(0 \mathrm{~h})=2738 \pm 274$ d.p.m./embryo. N.S. $=$ not significant, $P>0.05$. 


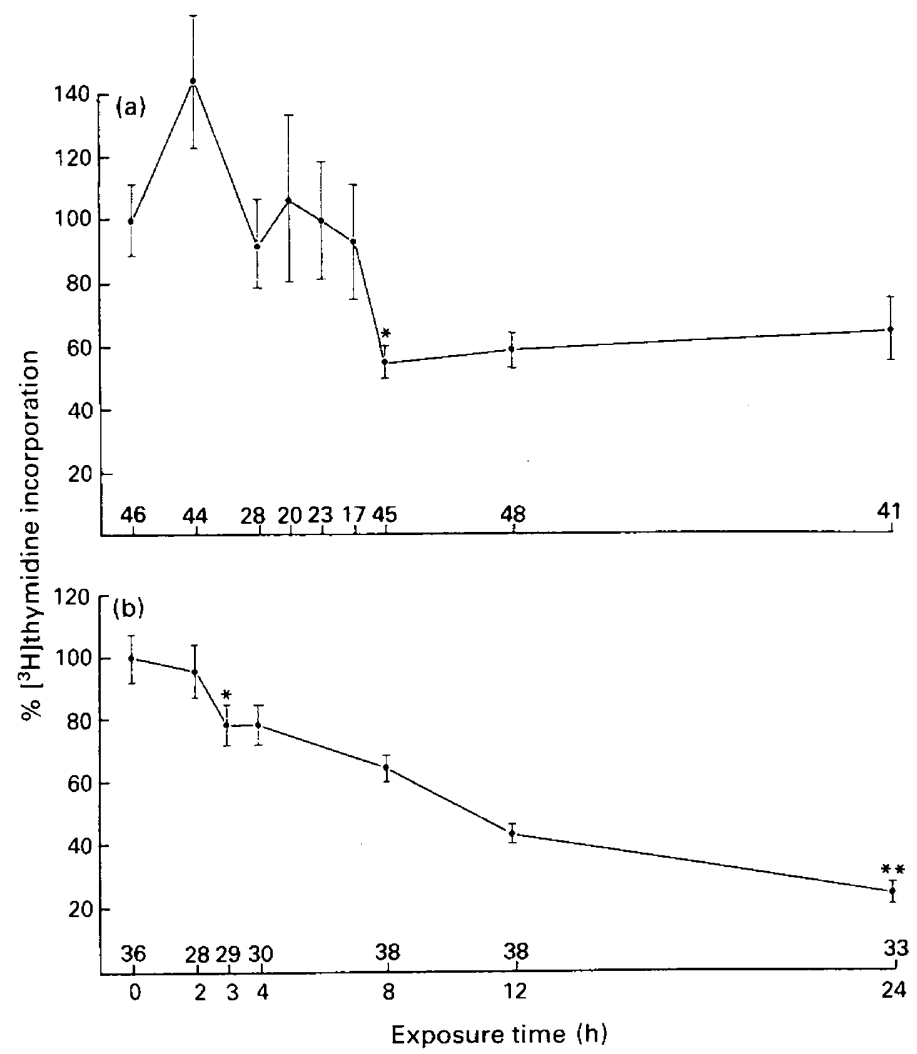

Fig. 4. $\left[{ }^{3} \mathrm{H}\right]$ Thymidine incorporation (as \% of non-exposed controls) in (a) Day-1 rabbit embryos and (b) Day-3 rabbit embryos exposed to room temperature. Values are mean \pm s.e.m. for the no. of embryos indicated. For (a), controls $(0 \mathrm{~h})=368 \pm 43$ d.p.m./embryo; for (b), controls $(0 \mathrm{~h})=2164 \pm 190$ d.p.m./embryo. ${ }^{*} P<0.05 ;{ }^{* *} P<0.01$ compared with controls $(0 \mathrm{~h})$.

2-cell to the morula stage, sensitivity to light exposure decreases while sensitivity to room temperature increases. Susceptibility can be demonstrated by threshold values of significantly decreased thymidine incorporation as well as by minimal incorporation levels persisting after elongated exposure. For both environmental factors studied the most severe effects were those of visible light on 2 -cell stages. As early as after $1 \mathrm{~h}$ exposure a statistically significant impairment of cell proliferation was detectable.

Similar to the present findings stage-specific susceptibility to physical factors has been reported for X-irradiation (Alexandre, 1974) and u.v. irradiation (Eibs \& Spielmann, 1977) in preimplantation mouse embryos. Stage-dependent susceptibility of rabbit embryos to temperatures below $37^{\circ} \mathrm{C}$ became manifest by differences in viability between cleavage stages and blastocysts after storage at $10^{\circ} \mathrm{C}$ (Chang, 1948a, b, 1950).

Irradiation experiments indicate that the deleterious effects of light are probably attributable to DNA lesions. Ultraviolet irradiation of preimplantation mouse embryos (Müller \& Spindle, 1986) and mammalian cells in culture (Kato, 1977) led to a significant increase in sister-chromatid exchange, provoked the induction of pyrimidine dimers (Beukers \& Berends, 1961), produced single-strand breaks in DNA (Elkind, 1971; Friedman et al., 1975) and was followed by excision repair (Pedersen \& Cleaver, 1975) and post-replication repair of DNA (Eibs \& Spielmann, 1977; Müller \& Spindle, 1986). Cell damage after irradiation depends on the duration of exposure, 
radiation intensity and on the wavelengths emitted. Daniel (1964) observed an inhibition of cleavage in Day-1 rabbit embryos after $12 \mathrm{~h}$ exposure to visible light. In the present study the 2-cell stage embryos cleaved at least once after $12 \mathrm{~h}$ and even after $24 \mathrm{~h}$ exposure to light. The different results might be explained by the higher light intensity (2600 lx) used by Daniel (1964). Emission values ranged from 320 to $740 \mathrm{~nm}$ in our study (see Fig. 1). Damage provoked by wavelengths below $300 \mathrm{~nm}$ should be negligible because the plastic of the culture dishes absorbs more than $99 \%$ of these ultraviolet wavelengths (Rauth, 1970; Bradley \& Sharkey, 1977). Emissions in the range of 300-500 $\mathrm{nm}$ seem to be more important, as shown by the use of appropriate filters for the protection of early rabbit embryos (Daniel, 1964) and in the damage of human D 98/ $\mathrm{AH}_{2}$ cells (Wang, 1975) and hamster oocytes (Hirao \& Yanagimachi, 1978a). The near-ultraviolet range (300-400 nm) was particularly suspected of causing cell death in different mammatian cells in culture (Wang et al., 1974). There are indications that a small but significant portion of light in the spectrum of $>500 \mathrm{~nm}$ penetrates transabdominally into the uterine lumen of mammals (Jacques et al., 1987). Jacques et al. (1987) suggest that light may induce direct and/or indirect beneficial effects on fetal development, e.g. concerning circadian rhythms.

Photochemical reactions between light and components of the culture medium have been reported to cause lethal effects on various mammalian cells (Stoien \& Wang, 1974; Wang, 1975; Pereira et al., 1976). To exclude such influences we pre-irradiated for $24 \mathrm{~h}$ medium which was to be used for cultures. The incorporation data of embryos cultured in this medium were not different from those of controls (data not shown), indicating that the deleterious effects of light were not due to phototoxic reactions within the culture medium. Light therefore seems to damage blastomeres directly.

Each physical factor investigated in the present study most probably affects blastomeres at different cellular targets. In a related study we found ultrastructural evidence that light provoked mainly cell degeneration and cell death while room temperature seemed to alter cytoskeleton organization and intracellular transport of organelles (Hegele-Hartung et al., 1988). The dynamic equilibrium between free tubulin and polymerized microtubules (Pickering \& Johnson, 1987) and molecular mechanisms of membrane fluidity (Breisblatt \& Ohki, 1975; Jacobson \& Papahadjopoulos, 1975) also seem to be influenced by temperature. Cooling leads to a depression of rabbit embryonic metabolism during storage at $10^{\circ} \mathrm{C}$ (Anderson \& Foote, 1974, 1975b). After rewarming, energy metabolism as well as nucleic acid and protein synthesis were not significantly decreased compared with controls cultured continuously at $37^{\circ} \mathrm{C}$. However, the number of embryos developing into blastocysts was clearly reduced after cooling (Anderson \& Foote, 1975a). In agreement with these findings we observed no blastocyst formation in Day-3 rabbit embryos after exposure to room temperature for $24 \mathrm{~h}$, while all light-exposed morulae did cavitate. Possible mechanisms involved may be temperature-sensitive trophoblast transport systems which are essential for accumulation of fluid, a prerequisite for blastocyst formation and expansion. Measurements of transtrophoblast potential difference (Cross \& Brinster, 1970) and reconstitution of blastocysts after mechanical injury (Daniel, 1963) indicated an optimum temperature in the $34-37^{\circ} \mathrm{C}$ range.

The mode of light or room temperature exposure did not display a significant effect on thymidine incorporation. Short split-dose exposures of Day-l embryos to visible light (e.g. $4 \times 1 \mathrm{~h}$ ) and of Day-3 embryos to room temperature (e.g. $4 \times 2$ h) revealed no statistically significant differences in incorporation values compared with embryos subjected to a single long exposure ( $4 \mathrm{~h}$ and $8 \mathrm{~h}$, respectively). Obviously, the periods between the exposure times did not allow significant recovery or, alternatively, the induced damage was irreversible. Relevant for laboratory conditions is the combined action of both stressors. Early results indicate that a simultaneous exposure towards light and room temperature does amplify the adverse effects (B. Fischer, A. Schumacher, C. Hegele-Hartung \& H. M. Beier, unpublished observation).

The amount of damage to and viability of embryos depends on the number of cells surviving after exposure. The reports of Seidel $(1952,1960)$ and Tarkowski \& Wróblewska (1967) clearly 
indicate the ability of single blastomeres to regulate and to secure further development. Embryo transfer experiments with exposed embryos will therefore have to be performed. The inevitable exposure to visible light and room temperature of human embryos in in-vitro fertilization/embryo transfer programmes could contribute to the surprisingly low rate of pregnancies after embryo replacement.

We thank Dr Thomas Jung for helpful discussions; Dr Guido Giani for statistical analyses; Susanne Echterhagen and Sabina Hennes for expert technical help; and Gisela Mathieu and Ursula Peters for typing the manuscript. This work was supported by a grant from the Deutsche Forschungsgemeinschaft within the research programme on "Biologie und Klinik der Reproduktion" (Fi 306/1-3).

\section{References}

Alexandre, H.L. (1974) Effects of X-irradiation on preimplantation mouse embryos cultured in vitro. $J$. Reprod. Fert. 36, 417-420.

Anderson, G.B. \& Foote, R.H. (1974) Effects of low temperature storage upon subsequent energy metabolism of rabbit embryos. Expl Cell Res. 87, 302-306.

Anderson, G.B. \& Foote, R.H. (1975a) Development of rabbit embryos in vitro and in vivo following storage of the two-cell stage at $10^{\circ} \mathrm{C} . J$. Reprod. Fert. 45, 151-153.

Anderson, G.B. \& Foote, R.H. (1975b) Effects of low temperature upon subsequent nucleic acid and protein synthesis of rabbit embryos. Expl Cell Res. 90, 73-78.

Barros, C., Herrera, E., Fuenzalida, I. \& Arguello, B. (1986) Hamster oocyte fertilizability after $4^{\circ} \mathrm{C}$ storage. Gamete Res. 14, 149-157.

Beukers, R. \& Berends, W. (1961) The effects of U.V.irradiation on nucleic acids and their components. Biochim. Biophys. Acta. 49, 181-189.

Bradley, M.O. \& Sharkey, N.A. (1977) Mutagenicity and toxicity of visible fluorescent light to cultured mammalian cells. Nature, Lond. 266, 724-726.

Breisblatt, W. \& Ohki, S. (1975) Fusion in phospholipid spherical membranes. I. Effect of temperature and lysolecithin. J. Membrane Biol. 23, 385-401.

Chang, M.C. (1947) Normal development of fertilized rabbit ova stored at low temperature for several days. Nature, Lond. 159, 602-603.

Chang, M.C. (1948a) Transplantation of fertilized rabbit ova: the effect on viability of age, in vitro storage period, and storage temperature. Nature, Lond. 161, 978-979.

Chang, M.C. (1948b) Probability of normal development after transplantation of fertilized rabbit ova stored at different temperatures. Proc. Soc. exp. Biol. Med. 68, 680-683.

Chang, M.C. (1948c) The effects of low temperature on fertilized rabbit ova in vitro, and the normal development of ova kept at low temperature for several days. J. gen. Physiol. 31, 385-409.

Chang, M.C. (1950) Transplantation of rabbit blastocysts at late stage: probability of normal development and viability at low temperature. Science, N.Y. 111, 544-545.

Cross, M.H. \& Brinster, R.L. (1970) Influence of ions, inhibitors and anoxia on transtrophoblast potential of rabbit blastocyst. Expl Cell Res. 62, 303-309.

Daniel, J.C., Jr (1963) Some kinetics of blastocyst formation as studied by the process of reconstitution. $J$. exp. Zool. 154, 231-237.

Daniel, J.C., Jr (1964) Cleavage of mammalian ova inhibited by visible light. Nature, Lond. 201, 316-317.

Dulbecco, R. \& Vogt, M. (1954) Plaque formation and isolation of pure lines with poliomyelitis viruses. $J$. exp. Med. 99, 167-182.

Eibs, H.G. \& Spielmann, H. (1977) Differential sensitivity of preimplantation mouse embryos to UV irradiation in vitro and evidence for postreplication repair. $R a d$. Res. 71, 367-376.

Elkind, M.M. (1971) Sedimentation of DNA released from chinese hamster cells. Biophys. J. 11, 502-520.

Fischer, B. (1987) Development retardation in cultured preimplantation rabbit embryos. J. Reprod. Fert. 79, $115-123$.

Fischer, B. \& Meuser-Odenkirchen, G. (1988) A two year follow-up of effects of biotechniques on reproduction in the domestic rabbit, Oryctolagus cuniculus. Lab. Anim. 22, 5-15.

Friedman, C.A., Kohn, K.W. \& Erickson, L.C. (1975) DNA chain growth during replication of asynchronous L1210 cells. Alkaline sedimentation studies. Biochemistry, N.Y. 14, 4018-4023.

Hafez, E.S.E. (1963) Storage of fertilized ova. Int. J. Fert. 8, 459-466.

Hafez, E.S.E. (1969) Superovulation and preservation of mammalian eggs. Acta endocrin., Copenh., Suppl. 140, 62, Abstr.

Hegele-Hartung, C., Schumacher, A. \& Fischer, B. (1988) Ultrastructure of preimplantation rabbit embryos exposed to visible light and room temperature. Anat. Embryol. 178, 229-241.

Hirao, Y. \& Yanagimachi, R. (1978a) Detrimental effect of visible light on meiosis of mammalian eggs in vitro. J. exp. Zool. 206, 365-370.

Hirao, Y.\& Yanagimachi, R. (1978b) Temperature dependence of sperm-egg fusion and post-fusion events in hamster fertilization. J.exp. Zool. 205, 433-438.

Jacobson, K. \& Papahadjopoulos, D. (1975) Phase transitions and phase separations in phospholipid membranes induced by changes in temperature, $\mathrm{pH}$, and concentration of bivalent cations. Biochemistry, N.Y. $14,152-161$. 
Jacques, S.L., Weaver, D.R. \& Reppert, S.M. (1987) Penetration of light into the uterus of pregnant mammals. Photochem. Photobiol. 45, 637-641.

Kato, H. (1977) Spontaneous and induced sister chromatid exchanges as revealed by the BUdR-labeling method. Int. Rev. Cytol. 49, 55-97.

Katska, L. \& Smorag, Z. (1985) The influence of culture temperature on in vitro maturation of bovine oocytes. Anim. Reprod. Sci. 9, 205-212.

Lenz, R.W., Ball, G.D., Leibfried, M.L., Ax, R.L. \& First, N.L. (1983) In vitro maturation and fertilization of bovine oocytes are temperature-dependent processes. Biol. Reprod. 29, 173-179.

Maurer, R.R. (1978) Advances in rabbit embryo culture. In Methods in Mammalian Reproduction, pp. 259-272. Ed. J. C. Daniel, Jr. Academic Press, New York.

Moor, R.M. \& Crosby, I.M. (1985) Temperature-induced abnormalities in sheep oocytes during maturation. $J$. Reprod. Fert. 75, 467-473.

Morstin, J. \& Katska, L. (1986) Effects of temperature on the ultrastructure of bovine oocytes in culture. Anim. Reprod. Sci. 12, 13-19.

Müller, W.-U. \& Spindle, A. (1986) Induction of sister chromatid exchange in preimplantation mouse embryos in vitro by ${ }^{3} \mathrm{H}$-thymidine or ultraviolet light in combination with caffeine. Teratogen., Carcinogen., Mutagen. 6, 107-114.

Pedersen, R.A. \& Cleaver, J.E. (1975) Repair of UV damage to DNA of implantation-stage mouse embryos in vitro. Expl Cell Res. 95, 247-250.

Pereira, O.M., Smith, J.R. \& Packer, L. (1976) Photosensitization of human diploid cell cultures by intracellular flavins and protection by antioxidants. Photochem. Photobiol. 24, 237-242.

Pickering, S.J. \& Johnson, M.H. (1987) The influence of cooling on the organization of the meiotic spindle of the mouse oocyte. Hum. Reprod. 2, 207-216.
Rauth, A.M. (1970) Effects of ultraviolet light on mammalian cells in culture. In Current Topics in Radiation Research, Vol. 6, pp. 196-248. Eds M. Ebert \& A. Howard. North-Holland, Amsterdam.

Seidel, F. (1952) Die Entwicklungspotenzen einer isolierten Blastomere des Zweizellstadiums in Säugetierei. Nátúrwissenschaften 39, 355-356.

Seidel, F. (1960) Die Entwicklungsfähigkeit isolierter Furchungszellen aus dem Ei des Kaninchens, Oryctolagus cuniculus. Wilhelm Roux' Arch. Entw. Mech. Org. 152, 43-130.

Stoien, J.D. \& Wang, R.J. (1974) Effect of nearultraviolet and visible light on mammalian cells in culture. II. Formation of toxic photoproducts in tissue culture medium by blacklight. Proc. natn. Acad. Sci. U.S.A. 71, 3961-3965.

Syms, A.J., Johnson, A.R., Lipshultz, L.I. \& Smith, R.G. (1985) Effect of aging and cold temperature storage of hamster ova as assessed in the sperm penetration assay. Fert. Steril. 43, 766-772.

Tarkowski, A.J. \& Wróblewska, J. (1967) Development of blastomeres of mouse eggs isolated at the 4- and 8cell stage. J. Embryol. exp. Morph. 18, 155-180.

Wang, R.J. (1975) Lethal effect of 'daylight' fluorescent light on human cells in tissue-culture medium. Photochem. Photobiol. 21, 373-375.

Wang, R.J., Stoien, J.D. \& Landa, F. (1974) Lethal effect of near-ultraviolet irradiation on mammalian cells in culture. Nature, Lond. 247, 43-45.

Whittingham, D.G. \& Wales, R.G. (1969) Storage of twocell mouse embryos in vitro. Aust. J. biol. Sci. 22, $1065-1068$.

Wilmut, I. (1986) Cryopreservation of mammalian eggs and embryos. In Manipulation of Mammalian Development, pp. 217-247. Ed. R. B. L. Gwatkin. Plenum Press, New York.

Received 11 January 1988 